\title{
Cytotoxicity and anti-inflammatory activities of Gallesia integrifolia (Phytolaccaceae) fruit essential oil
}

\author{
Wanessa de Campos Bortolucci, Keila Fernanda Raimundo, Carla Maria \\ Mariano Fernandez, Ricardo C. Calhelha, Isabel C. F. R. Ferreira, Lillian \\ Barros, José Eduardo Gonçalves, Giani Andrea Linde, Nelson Barros Colauto \\ \& Zilda Cristiani Gazim
}

To cite this article: Wanessa de Campos Bortolucci, Keila Fernanda Raimundo, Carla Maria Mariano Fernandez, Ricardo C. Calhelha, Isabel C. F. R. Ferreira, Lillian Barros, José Eduardo Gonçalves, Giani Andrea Linde, Nelson Barros Colauto \& Zilda Cristiani Gazim (2021): Cytotoxicity and anti-inflammatory activities of Gallesia integrifolia (Phytolaccaceae) fruit essential oil, Natural Product Research, DOI: 10.1080/14786419.2021.1925270

To link to this article: https://doi.org/10.1080/14786419.2021.1925270

View supplementary material ¿

Published online: 18 May 2021.

Submit your article to this journal 주

III Article views: 81

Q View related articles $\sqsubset$

View Crossmark data $\widetilde{ }$ 


\title{
Cytotoxicity and anti-inflammatory activities of Gallesia integrifolia (Phytolaccaceae) fruit essential oil
}

\author{
Wanessa de Campos Bortolucci ${ }^{\mathrm{a}}$ (D), Keila Fernanda Raimundo ${ }^{\mathrm{b}}$ (D), \\ Carla Maria Mariano Fernandez ${ }^{a}$ (D) Ricardo C. Calhelha ${ }^{c}$ (D), Isabel C. F. R.
} Ferreira $^{c}$ (D), Lillian Barros ${ }^{c}$ (D), José Eduardo Gonçalves ${ }^{d}$ (D), Giani Andrea Linde ${ }^{a}$ (D), Nelson Barros Colauto ${ }^{a}$ (D) and Zilda Cristiani Gazim ${ }^{a}$ aPrograma de Pós-Graduação em Biotecnologia aplicada à Agricultura, Universidade Paranaense,
Praça Mascarenhas de Moraes, Umuarama, Paraná, Brazil; 'bInstituto Federal do Paraná (IFPR) Campus
Umuarama, Umuarama, Paraná, Brazil; 'CCentro de Investigação de Montanha (CIMO), Instituto
Politécnico de Bragança, Bragança, Portugal; 'P Programa de Pós-Graduação em Tecnologias Limpas e
Cesumar Instituto de Ciências, tecnologia e Inovação, UniCesumar, Maringá, Paraná, Brazil

\section{ABSTRACT}

The chemical composition of Gallesia integrifolia fruits essential oil was obtained by hydrodistillation using a modified Clevenger apparatus was investigated by gas chromatography coupled to mass spectrometry (GC/MS). In addition, the cytotoxicity activity against human tumor cell lines MCF-7 (breast adenocarcinoma), $\mathrm{NCl}-\mathrm{H} 460$ (large cell lung carcinoma), HeLa (cervical carcinoma), and HepG2 (hepatocellular carcinoma), and non-tumor PLP2 (porcine liver primary cells) as well as the anti-inflammatory action was proposal. The compounds were predominantly organosulfates (2,8-dithianonane, dimethyl trisulfide, and lenthionine). Antiinflammatory activity that provides $50 \%$ inhibition of nitric oxide production $(55 \mu \mathrm{g} / \mathrm{mL})$ of essential oil of the fruits. It also presents cytotoxic activity against MCF-7 $\left(\mathrm{Gl}_{50}=66 \mu \mathrm{g} / \mathrm{mL}\right), \quad \mathrm{NCl}-\mathrm{H}-460$ $\left(\mathrm{Gl}_{50}=147 \mu \mathrm{g} / \mathrm{mL}\right)$, HeLa $\left(\mathrm{Gl}_{50}=182 \mu \mathrm{g} / \mathrm{mL}\right)$ and HepG2 $\left(\mathrm{Gl}_{50}=\right.$ $240 \mu \mathrm{g} / \mathrm{mL}$ ). The essential oil is more active in tumor cells than in non-tumor cells and the $\mathrm{Gl}_{50}$ values for essential oil reported in our work support future studies.

\section{Gallesia integrifolia essential oil fruits}
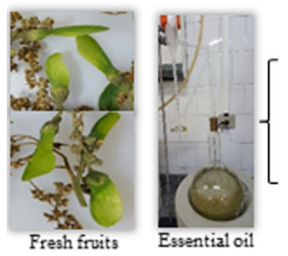

Major compounds

\section{Biological actirities}

- Inhibited the production of nitric oxide with

$\left(\mathrm{EC}_{50} \quad 55 \mu \mathrm{g} / \mathrm{mL}\right)$;

- Not cytotonicity in PLP2 cells $\left(\mathrm{GI}_{50}>\right.$

$\{400 \mu \mathrm{g} / \mathrm{mL}$ );

- Cytotoxicity for the tumor cell lines MCF-7

$\left(\mathrm{GI}_{50} 66 \mu \mathrm{g} / \mathrm{mL}\right)$.

\section{ARTICLE HISTORY}

Received 19 July 2020

Accepted 26 April 2021

\section{KEYWORDS}

Essential oil; inflammation; antitumoral; organosulfurates; Pau d'alho

CONTACT Zilda Cristiani Gazim cristianigazim@prof.unipar.br

$(+)$ Supplemental data for this article can be accessed online at https://doi.org/10.1080/14786419.2021.1925270. 


\section{Introduction}

Gallesia integrifolia (Spreng.) Harms (Phytolaccaceae) is a tree native to the Atlantic forest of Brazil. This species is popularly known as pau d'alho in Brazil due to its characteristic alliaceous odor. In popular medicine, it is utilized by quilombo communities and rural settlements in the northern region of Rio de Janeiro state in Brazil to treat the flu, bronchitis, inflammations, memory disorders, mycosis, and as a sedative (Neves 2012). In addition, it is used to treat pneumonia, vermin, gonorrhea, prostate tumors, and rheumatism (Lorenzi 2002).

Several classes of phytochemicals from different parts of $G$. integrifolia have been reported, including terpenes, porphyrins, branched alcohols, phenols, aromatic ketones, and sulfur-containing natural substances. In the essential oil were reported sulfur compounds in the leaves (97.00\%), flowers (93.33\%) and fruits $(86.74 \%)$. In the fruits the main compounds were 2,3,5-trithiahexane, 6-dithiaoctan-1,8-diol, Methanethiol (Raimundo et al. 2017), 2,8-Dithianonane, Dimethyl trisulfide and Lenthionine with antimicrobial potential (Raimundo et al. 2018). For the crude extract of the fruits also, the main compounds were sulfur (9.11\%) as 2,4-dithiapentane (2.26\%), 2 1,2,4-trithiolane (1.87\%) and 2,3,5-trithiahexane (4.98\%). The extracts and essential oil of $G$. integrifolia are reported to have larvicidal, antifungal, acaricidal, antiulcer, antinociceptive, anti-inflammatory and antiviral activities (Silva Júnior et al. 2013; Arunachalam et al. 2017; Raimundo et al. 2017; Raimundo et al. 2018). However, studies on cytotoxic activity of $G$. integrifolia fruit essential oil have not been found. Thus, this study aimed to evaluate the chemical composition and the cytotoxic and antiinflammatory activities of $G$. integrifolia fruit essential oil.

\section{Results and discussion}

The yield of $G$. integrifolia fruit colorless essential oil was $0.5 \mathrm{~mL} / \mathrm{kg}(0.05 \pm 0.006 \%)$ with density of $1.48 \mathrm{~g} / \mathrm{mL}$ and refraction index of 1620 . The results for the fruit essential oil have density and refractive index in accordance to Raimundo et al. (2017). The chemical composition analysis of the essential oil identified 29 constituents with the predominance of organosulfurate compounds (Table S1). The major compounds were 2,8-dithianonane (52.9\%), dimethyl trisulfide (15.2\%), and lenthionine (14.8\%) (Table S1; Figures S1-S4). The presence of sulfureted compounds in the essential oil is related to the characteristic alliaceous odor (Akisue et al. 1986). The results found in the present study are in agreement with Raimundo et al. (2018). Among the 29 identified compounds, five of them such as 4-methyl-2-thianonane, 1-oxa-4,7-dithiononane disulfide, bis (2-sulfhydryl ethyl), 2-(octylthio) ethanol, and propane, 1,1'-thiobis [3-(methylthio)]) have not yet been reported for plants. Thus, we suggest that these five compounds might be artifacts produced during the extraction process (Venditti 2018) or that they are unique compounds from G. integrifolia and, in that case, they need further studies (Table S4). The remaining 24 compounds have already been reported for $G$. integrifolia and other plants in a diversity of botanical families (Table S4).

Organosulfurates are secondary metabolites characterized by a sulfur atom linked to the cyanate group, produced by vegetables, and based on sulfureted amino acids such as methionine and cysteine, which provide the synthesis of organosulfur 
compounds through thermal or enzymatic processes (Kyung and Lee 2001; Dewick 2002); therefore, they are able to direct the synthesis of organosulfur compounds.

Therefore, methionine, an amino acid found in Phytolaccaceae species (Dewick 2002), degrades by thermal process and produces methional, which in turn degrades itself and originates sulfur compounds. One of these products is methanethiol which can be transformed into dimethyl disulfide in the presence of oxygen (Schutte and Teranishi 1974) and, through a transfer reaction of the methyl group, it can also form dimethyl sulfide (Lomans et al. 2002).

Sulfur-containing defense compounds are crucial for plant survival during biotic and abiotic stress such as temperature (heat or chilling), water (drought or flooding), salinity, proton toxicity, heavy metals, overexposure to ultraviolet rays, ozone, and others. For that, the plant produces elemental sulfur, hydrogen sulfide, glutathione, phytochelatins, sulfur rich proteins and various secondary metabolites (Capaldi et al. 2015). The formation of these compounds in plants is closely related to the supply, demand, uptake, and assimilation of sulfur (Anjum et al. 2015; Putnik et al. 2019).

The fruit essential oil inhibited the production of nitric oxide with $\mathrm{EC}_{50}$ of $55 \mu \mathrm{g} / \mathrm{mL}$, a value that is 3.4-fold higher than the positive control dexamethasone $(16 \mu \mathrm{g} / \mathrm{mL})$ (Table S2). However, although the fruit essential was less effective, it is important to consider that dexamethasone is an isolated compound, and the essential oil is a mixture of chemical compounds. The anti-inflammatory activity of the fruit essential oil found in our study supports the popular use of this species to treat inflammations (Neves 2012).

The anti-inflammatory potential of the fruit essential oil from G. integrifolia can also be related to the presence of sulfur compounds, as the molecules that donate hydrogen sulfide $\left(\mathrm{H}_{2} \mathrm{~S}\right)$ have anti-inflammatory activity (Bátai et al. 2018). Hydrogen sulfide activates T-type CaV 3.2 channels that modulate the feeling of pain in sensory neurons, inhibit voltage-dependent $\mathrm{K}^{+}$channels contributing to the depolarization of peptidergic sensory neurons and somatostatin release of these cells, have anti-proliferative effect in T cells, and induce polymorphonuclear cell apoptosis. However, high concentrations of $\mathrm{H}_{2} \mathrm{~S}$ have pro-inflammatory effects (Wang 2012; Bátai et al. 2018).

Moreover, the fruit essential oil inhibited the growth of four human tumor cell lines with $\mathrm{Gl}_{50}$ value of $66 \mu \mathrm{g} / \mathrm{mL}$ for MCF-7, $147 \mu \mathrm{g} / \mathrm{mL}$ for $\mathrm{NCl}-\mathrm{H}-460,182 \mu \mathrm{g} / \mathrm{mL}$ for HeLa, and $240 \mu \mathrm{g} / \mathrm{mL}$ for HepG2 (Table S3). This is very promising and desirable in the treatment of neoplasms. According to Suffness and Pezzuto (1990), and Boik (2001) essential oils with $\mathrm{Gl}_{50}<$ than $30 \mu \mathrm{g} / \mathrm{mL}$ and pure compounds with $\mathrm{Gl}_{50}<4 \mu \mathrm{g} / \mathrm{mL}$ are considered promising values. So, the $\mathrm{Gl}_{50}$ values for $G$. integrifolia fruit essential reported in our work could support future studies.

Our results made evident that the fruit essential oil from $G$. integrifolia had moderate cytotoxic activity against human tumor cell lines, but no cytotoxic activity against porcine non-tumor cells. The SI of the fruit essential oil - which is the relation between $\mathrm{Gl}_{50}$ value of non-tumor cells divided by tumor cells (Almeida et al. 2014) was over 6.06. Thus, this essential oil is more active in tumor cells than in non-tumor cells and, therefore, more selective and appropriate for the use against neoplastic cells. The cytotoxicity activity of the essential oil of the fruits of $G$. integrifolia is described for the first time in the literature. 
The 2,8-dithianonane (52.9\%) compound (Figure S2), a major compound in the fruit essential oil of our study has been synthesized since 1980 and its molecular structure $\left(\mathrm{C}_{7} \mathrm{H}_{16} \mathrm{~S}_{2}\right)$ has two sulfur atoms (Golovnya et al. 1980). Only Raimundo et al. (2018) reported this compound as the major one (52.6\%) in G. integrifolia fruit essential oil. Dimethyl trisulfide (15.2\%), which is a hydrogen sulfide $\left(\mathrm{H}_{2} \mathrm{~S}\right)$ donor, was the second most abundant compound in the fruit essential oil of our study. It is a compound belonging to the polysulfide group, utilized as food additive and as antidote for cyanide poisoning. Furthermore, it has been reported to have anti-inflammatory and antinociceptive activities in an animal model (Bátai et al. 2018). Lenthionine (14.8\%), the third major compound in the fruit essential oil of our study, was reported in the mushroom aqueous extract of Lentinus edodes (Berk.) Singer (current name Lentinula edodes (Berk.) Pegler) with anti-inflammatory activity similar to prednisone $(1 \mu \mathrm{mol} / \mathrm{L})$ (Kupcová et al. 2018). However, this compound has low antitumor activity in relatively high doses $(10-20 \mu \mathrm{g} / \mathrm{mL})$ against cell lines in human liver carcinoma, human cervical carcinoma, and human pancreas carcinoma (Kupcová et al. 2018).

There are no reports in the literature on the cytotoxicity of the fruit essential oil from G. integrifolia; however, dimethyl trisulfide (15.2\%) (Figure S3) found in the fruit essential oil of our study induced cytoprotection against cell death and aging, caused by oxidative stress by a catalytic mechanism medium of mitochondrial peptide methionine sulfoxide reductase protein (Guan et al. 2017). Compounds containing sulfur, mainly from Allium sp. and Brassica sp., have shown protective effect against different types of neoplasia by apoptosis (De Gianni and Fimognari 2015). Our results indicate that $G$. integrifolia fruit essential oil was selectively cytotoxic for all tested tumor cells and that the possible mechanism of action can be related to the presence of sulfur compounds. Future studies are needed to evaluate the mechanism of action and the compounds responsible for biological activity.

\section{Experimental}

Supplementary material related to this paper is available online, alongside Tables S1-S4 and Figures S1-S2.

\section{Conclusion}

The fruit essential oil from $G$. integrifolia has a predominance of organosulfurate compounds and the major compounds are 2,8-dithianonane, dimethyl trisulfide, and lenthionine. The essential oil is more active in tumor cells than in non-tumor cells and the $\mathrm{Gl}_{50}$ values for essential oil reported in our work support future studies. This is the first study reported on the cytotoxicity of $G$. integrifolia fruit essential oil.

\section{Acknowledgments}

The authors thank Universidade Paranaense, UniCesumar, Foundation for Science and Technology (FCT, Portugal) and FEDER under Programme PT2020 for financial support to CIMO (UID/AGR/00690/2019) and to national funding by FCT, P.I., through the institutional scientific employment program-contract for R.C. Calhelhas contract, Coordenação de Aperfeiçoamento de 
Pessoal de Nível Superior - Brazil (CAPES) -finance code 001-, Conselho Nacional de Desenvolvimento Científico e Tecnológico (CNPq), and Fundação Araucária for the financial support and the fellowship.

\section{Disclosure statement}

The authors declare no conflicts of interest.

\section{ORCID}

Wanessa de Campos Bortolucci (D) http://orcid.org/0000-0002-7233-8313

Keila Fernanda Raimundo (D) http://orcid.org/0000-0003-2702-1592

Carla Maria Mariano Fernandez (D) http://orcid.org/0000-0001-7324-5533

Ricardo C. Calhelha (D) http://orcid.org/0000-0002-6801-4578

Isabel C. F. R. Ferreira (D) http://orcid.org/0000-0003-4910-4882

Lillian Barros (iD http://orcid.org/0000-0002-9050-5189

José Eduardo Gonçalves (D) http://orcid.org/0000-0002-2505-0536

Giani Andrea Linde (D) http://orcid.org/0000-0003-1220-2032

Nelson Barros Colauto (D) http://orcid.org/0000-0003-4390-8302

Zilda Cristiani Gazim (D) http://orcid.org/0000-0003-0392-5976

\section{References}

Akisue MK, Akisue G, Oliveira F. 1986. Pharmacognostic characterization of pau d'alho (Gallesia integrifolia (Spreng.) Harms.). Rev Bras Farmacogn. 1(2):166-182.

Almeida TL, Monteiro JA, Lopes GKP, Chiacelli LUR, Santin SMO, Silva CC, Kaplum V, Scariot DB, Nakamura CV, Ruiz ALTG, et al. 2014. Chemical study and antiproliferative, trypanocidal and leishmanicidal activities of Maxillaria picta. Quim Nova. 37(7):1151-1157.

Anjum NA, Gill R, Kaushik M, Hasanuzzaman M, Pereira E, Ahmad I, Tuteja N, Gill SS. 2015. ATPsulfurylase, sulfur-compounds, and plant stress tolerance. Front Plant Sci. 6:210.

Arunachalam K, Balogun SO, Pavan E, de Almeida GVB, de Oliveira RG, Wagner T, Cechinel Filho V, de Oliveira Martins DT. 2017. Chemical characterization, toxicology and mechanism of gastric antiulcer action of essential oil from Gallesia integrifolia (Spreng.) Harms in the in vitro and in vivo experimental models. Biomed Pharmacother. 94:292-306.

Bátai IZ, Horváth Á, Pintér E, Helyes Z, Pozsgai G. 2018. Role of transient receptor potential ankyrin 1 ion channel and somatostatin sst 4 receptor in the antinociceptive and anti-inflammatory effects of sodium polysulfide and dimethyl trisulfide. Front Endocrinol. 9:55.

Boik J. 2001. Natural compounds in cancer therapy. Princeton, MN: Oregon Medical Press. p. 25.

Capaldi FR, Gratão PL, Reis AR, Lima LW, Azevedo RA. 2015. Sulfur metabolism and stress defense responses in plants. Trop Plant Biol. 8(3-4):60-73.

De Gianni E, Fimognari C. 2015. Anticancer mechanism of sulfur-containing compounds. Enzymes 37:167-192.

Dewick PM. 2002. Medicinal natural products: a biosynthetic approach. 2nd ed. New York: John Wiley \& Sons Ltd.

Golovnya RV, Misharina TA, Garbuzov VG. 1980. Gas-chromatographic characteristics of sulfurcontaining compounds. Russ Chem Bull. 29(11):1765-1769.

Guan XL, Wu PF, Wang S, Zhang JJ, Shen ZC, Luo H, Chen H, Long LH, Chen JG, Wang F. 2017. Dimethyl sulfide protects against oxidative stress and extends lifespan via a methionine sulfoxide reductase A-dependent catalytic mechanism. Aging Cell. 16(2):226-236.

Kupcová K, Štefanová I, Plavcová Z, Hošek J, Hrouzek P, Kubec R. 2018. Antimicrobial, cytotoxic, anti-inflammatory, and antioxidant activity of culinary processed shiitake medicinal mushroom 
(Lentinus edodes, Agaricomycetes) and Its major sulfur sensory-active compound-lenthionine. Int J Med Mushrooms. 20(2):165-175.

Kyung KH, Lee YC. 2001. Antimicrobial activities of sulfur compounds derived from S-alk (en) ylL-cysteine sulfoxides in allium and brassica. Food Rev Int. 17(2):183-198.

Lomans BP, Van der Drift C, Pol A, Op den Camp HJM. 2002. Microbial cycling of volatile organic sulfur compounds. Cell Mol Life Sci. 59(4):575-588.

Lorenzi H. 2002. Árvores brasileiras: Manual de identificação e cultivo de plantas arbóreas nativas do Brasil. São Paulo: Instituto Plantarum de Estudos da Flora Ltda, 368 p.

Neves FS. 2012. Estudo químico e microbiológico de Gallesia integrifolia (Spreng) Harms. (Phytolaccaceae). 123 f. Dissertação (Mestrado em Ciências Naturais) - Universidade Estadual do Norte Fluminense Darcy Ribeiro, Campos do Goytacazes.

Putnik P, Gabrić D, Roohinejad S, Barba FJ, Granato D, Mallikarjunan K, Lorenzo JM, Bursać Kovačević D. 2019. An overview of organosulfur compounds from Allium spp.: from processing and preservation to evaluation of their bioavailability, antimicrobial, and anti-inflammatory properties. Food Chem. 15:680-691.

Raimundo KF, Bortolucci WC, Glamočlija J, Soković M, Gonçalves JE, Linde GA, Colauto NB, Gazim ZC. 2018. Antifungal activity of Gallesia integrifolia fruit essential oil. Braz J Microbiol. 49(1):229-235.

Raimundo KF, Bortolucci WC, Silva ES, Pereira AFB, Sakai OA, Júnior RP, Gonçalves JE, Linde GA, Gazim ZC. 2017. Chemical composition of garlic wood (Gallesia integrifolia) (Phytolaccaceae) volatile compounds and their activity on cattle tick. Aust J Crop Sci. 11(08):1058-1067.

Schutte L, Teranishi R. 1974. Precursors of sulfur-containing flavor compounds. CRC Crit Rev Food Technol. 4(4):457-505.

Silva Júnior AJ, Buzzi FC, Romanos MTV, Wagner TM, Guimarães APC, Cechinel Filho V, Batista R. 2013. Chemical composition and antinociceptive, anti-inflammatory and antiviral activities of Gallesia gorazema (Phytolaccaceae), a potential candidate for novel anti-herpetic phytomedicines. J Ethnopharmacol. 150(2):595-600.

Suffness M, Pezzuto JM. 1990. Assays related to cancer drug discovery. In: Hostettmann K, editor. Methods in plant biochemistry: assays for bioactivity. London: Academic Press; p. 71-133.

Venditti A. 2018. What is and what should never be: artifacts, improbable phytochemicals, contaminants and natural products. Nat Prod Res. 34(7):1014-1031.

Wang R. 2012. Physiological implications of hydrogen sulfide: a whiff exploration that blossomed. Physiol Rev. 92:791-896. 